\title{
Examination of Science Teachers' Views Related to Tablet PC Using in Courses in Terms of Different Variables: Example of Giresun Province
}

\author{
Ŭ̆ur ÖZDEMİR', Aykut Emre BOZDOĞAN²
}

\section{Summary}

\section{PURPOSE}

Fatih project in education is a project which is run by Ministry of Education and supported by Ministry of Transportation. It is thought to be completed in five years. It is aimed that the needs for IT equipment and software foundations, e-content, up-dating of teacher's guide book, in-service training for teachers and conscious, secure and manageable IT and Internet use will be completed for secondary schools in the first year, primary schools in the second year, primary school first levels and pre-schools in the third year. As a part of this project, beginning with the $5^{\text {th }}$ and $9^{\text {th }}$ grades in 2012, all the students are meant to be provided with tablet PCs. It is early to estimate what tablet PCs will bring to education and teaching. But there is a known fact that a new technology's being brought into class environment causes excitement and doubt not only with the teachers but also with the students. The implementation of this innovation and its contribution to teaching-learning process depends undoubtedly on the attitudes of the teachers. It is not expected from the computer to cause an important affect unless teachers are trained and computers become an integral part of course syllabus. So, it is vital to take into consideration the attitudes of teachers before technologic change comes true for the precautions to be taken. With the study conducted with in this context, it is aimed at determining the attitudes of teachers towards computers and their ideas about tablet PCs and analysing them in terms of different variables. This study was conducted to determine the views of science teachers' about tablet computer project of Ministry of National Education FATIH Project in terms of different variables.

\section{METHOD}

Descriptive survey method was used in the research. The sample of this study consisted of 133 science teachers in 2012-2013 academic year who is working in Giresun province. The data were obtained by using survey form which was developed by researcher. The data were analyzed via SPSS (Statistical Package for the Social Sciences) by utilizing frequency, percentages and Chi-Square test.

\section{RESULTS and DISCUSSION}

The result of the study was showed that $83 \%$ of the teachers support using tablet PC in courses, $79 \%$ of them want to take courses in order to learn tablet PC using and $68 \%$ of them think that their school are suitable for tablet PC using. Also; it is found that there are significant differences in gender status of teachers, frequency of computer using and school status between the status of support tablet PC. In addition, according to science teachers, the most important advantages of tablet PC using in science courses "Science courses can more fun with visuals and animations", "Intangible things can be understood easily in science

${ }_{1}^{1}$ Giresun University, The Institute of Science, ugur4932@hotmail.com

2 Assoc. Prof., Giresun University, Faculty of Education, aykut.bozdogan@giresun.edu.tr 
courses" and "Effectiveness activities can be done with animations in science courses". They were also expressed the most disadvantages of tablet PC using in science courses "The radiation of tablet PC spread may give harm to health", "Unsuitable sites for courses like facebook, twitter can be entered by students" and "Social interaction can reduce among the students". 